DOI 10.32900/2312-8402-2020-123-21-30

УДК 615.012.1: 582.949.2: 581.3

\title{
IDENTIFICATION OF THE ANTIBACTERIAL EFFICACY OF ETHANOLIC EXTRACTS FROM AGLAONEMA COMMUTATUM SCHOTT LEAVES AND ITS CULTIVARS AGAINST ESCHERICHIA COLI STRAIN
}

Opryshko M., a post-graduate student

Gyrenko O., a post-graduate student

Buyun L., Doctor of Biological Sciences

M. M. Gryshko National Botanic Garden, National Academy of Science of Ukraine,

Tkachenko H., Doctor of Biological Sciences

Kurhaluk N., Doctor of Biological Sciences

Institute of Biology and Earth Sciences, Pomeranian University in Słupsk, Poland

Tomin V., Doctor of Physical Sciences

Department of Physics, Pomeranian University in Słupsk, Poland

This study aimed to evaluate the antibacterial activity of ethanolic extracts obtained from the leaves of Aglaonema commutatum Schott and its cultivars («Malay Beauty», "Silver Queen», and «Silver King») against Escherichia coli (Migula) Castellani and Chalmers $\left(A T C C^{\circledR} 25922^{\mathrm{TM}}\right)$ strain. The leaves of Aglaonema commutatum plants and its cultivars, cultivated under glasshouse conditions, were sampled at M. M. Gryshko National Botanic Garden (NBG), National Academy of Science of Ukraine (Kyiv, Ukraine). The leaves were brought into the laboratory for antimicrobial studies. Freshly sampled leaves were washed, weighed, and homogenized in $96 \%$ ethanol (in proportion 1:19) at room temperature. The extracts were then filtered and investigated for their antimicrobial activity. Escherichia coli (Migula) Castellani and Chalmers $\left(A T C C^{\circledR} 25922^{\mathrm{TM}}\right)$ strain was used in our study.

Antimicrobial activities of various ethanolic extracts obtained from leaves of Aglaonema commutatum plants and its cultivars («Malay Beauty», «Silver Queen», and «Silver King») against Escherichia coli (Migula) Castellani and Chalmers (ATCC ${ }^{\circledR}$ $25922^{\mathrm{TM}}$ ) strain was screened in the current study. The testing of the antibacterial activity of the plant extracts was carried out in vitro by the Kirby-Bauer disc diffusion technique. The leaf extracts from A. commutatum «Silver Queen» and A. commutatum 'Silver King' exhibited higher inhibitory activity than the extracts from A. commutatum and A. commutatum "Malay Beauty». Maximum in vitro inhibition was scored by A. commutatum «Silver Queen», followed by A. commutatum «Silver King», A. commutatum, and A. commutatum «Malay Beauty».

In particular, the leaf extracts from A. commutatum "Silver Queen» and A. commutatum 'Silver King' exhibited higher inhibitory activity than the extracts from A. commutatum and A. commutatum «Malay Beauty». Maximum in vitro inhibition was scored by A. commutatum «Silver Queen», followed by A. commutatum «Silver King», A. commutatum, and A. commutatum "Malay Beauty», which presented inhibition zones

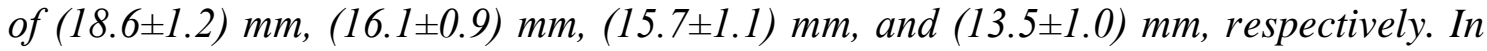
the case of the positive controls, $96 \%$ ethanol possesses a mild anti-E. coli effect, which presented inhibition zones of $(9.5 \pm 1.2) \mathrm{mm}$. The inhibition zone diameters were increased by $96 \%(p<0.05)$ for A. commutatum «Silver Queen», by $69 \%(p<0.05)$ for A. commutatum «Silver King», by $65 \%$ ( $p<0.05)$ for A. commutatum, and by $42 \%$ $(p<0.05)$ for A. commutatum «Malay Beauty».

Thus, the use of these plants in traditional medicine and veterinary medicine 
was experimentally confirmed as a potential source of raw materials for the development of medicines in the future, as well as for the development of innovative feed for farm animals.

Keywords: Aglaonema commutatum, antibacterial activity, Escherichia coli (Migula) Castellani and Chalmers $\left(\mathrm{ATCC}^{\circledR} \mathbf{2 5 9 2 2}^{\mathrm{TM}}\right)$ strain, Kirby-Bauer disc diffusion technique

The interest in the herbal medicines, phytochemical and biological prospecting and isolation of active compounds is growing incredibly in the few last decades. Medicinal plants are being practiced for different ailments in most of the developing countries [24]. Despite the rapid progress towards the field of medicinal chemistry, the resistance of microbes against therapeutic agents necessitates the search of novel therapeutic agents from medicinal plants [25]. Moreover, medicinal plant-based drugs can be a good alternative because of safety, biodegradability, and imposing fewer side effects [26].

The family Araceae, commonly known as aroids, encompasses 105 genera and more than 3,300 species that are mostly herbaceous either as terrestrial, aquatic, or epiphytic [13]. Aroids are extraordinarily diverse in appearance, with their attractive foliage being the most widely recognized feature. Some members of Araceae were used as ornamentals, indoor plants, food, fibers, medicinal, and biopesticide [13, 21]. It is believed that an important characteristic of aroids, which has not been completely appreciated, is that many are important medicinal plants [3].

The genus Aglaonema Schott (Araceae) is comprised of 21 species that inhabit humid and heavily shaded forests of many territories of Asia [3, 5, 6]. Aglaonema, one of the world's most popular houseplants, has provided a rich source of variation for the breeding of different foliage forms. This genus contains many cultivars that are important tropical foliage plants due to their tolerance to drought and low light and low relative humidity levels encountered under interior conditions [4].

There are many pieces of evidence of antioxidative [17], antimicrobial [18], photocytotoxic [2], etc. properties of Aglaonema spp. In recent years Aglaonema plants have been widely used because of its anti-aging and longevity properties, natural antiallergic, and anti-inflammatory activities [8, 12]. Moreover, a decoction of the roots is drunk to treat dropsy and fever [19]. Also, the genus Aglaonema can remove pollutants from the indoor air such as benzene, toluene, TCE, m-xylene, hexane, etc. Antihyperglycemic effects of N-containing sugars from Aglaonema treubii Engl. in diabetic mice were noted [15].

Studies have been undertaken on the constituents of methanol crude extracts, derived from the leaves, stems, and roots of Aglaonema simplex (Blume) Blume, an aquatic plant that has been widely distributed as ornamental plants [10]. The results showed that the extracts contained secondary metabolites belonging to the phenolics, alkaloids, terpenoids, steroids, and glycosides. Therefore, A. simplex is suggested as one of the potential sources of the plant-derived compounds for the treatment of atherosclerosis [10].

A literature survey of Roy and co-workers (2013) reveals that research works on antibacterial activity have been conducted on different plants of Araceae. Most of the plants under investigation have shown significant activity against different pathogenic bacteria. From the available data, taking into account the zones of inhibition, it could be concluded that the bacterial strains whose activities have been inhibited most by the secondary metabolites present in the crude extracts of the plants are Escherichia coli, Bacillus subtilis, Staphylococcus aureus, Klebsiella pneumonia, and Pseudomonas ae- 
ruginosa. A maximum zone of inhibition has been observed in the case of ethanol extract obtained from the tuber of Typhonium trilobatum having a $32 \mathrm{~mm}$ zone of inhibition against Staphylococcus aureus [23]. Nevertheless, very scarce information is available concerning the antimicrobial activity of the studied plant species.

Therefore, this study aimed to evaluate the antibacterial activity of ethanolic extracts obtained from the leaves of Aglaonema commutatum Schott and its cultivars ('Malay Beauty', 'Silver Queen', and 'Silver King') against Escherichia coli (Migula) Castellani and Chalmers (ATCC ${ }^{\circledR} 25922^{\mathrm{TM}}$ ) strain.

Materials and Methodology. Collection of Plant Materials and Preparation of Plant Extracts. The leaves of Aglaonema commutatum plants and its cultivars ('Malay Beauty', 'Silver Queen', and 'Silver King'), cultivated under glasshouse conditions, were sampled at M.M. Gryshko National Botanic Garden (NBG), National Academy of Science of Ukraine (Kyiv, Ukraine).

The leaves were brought into the laboratory for antimicrobial studies. Freshly sampled leaves were washed, weighed, and homogenized in 96\% ethanol (in proportion 1:19) at room temperature. The extracts were then filtered and investigated for their antimicrobial activity. Escherichia coli (Migula) Castellani and Chalmers (ATCC ${ }^{\circledR}$ $25922^{\mathrm{TM}}$ ) strain was used in our current study.

Determination of the antibacterial activity of plant extracts by the disk diffusion method. The testing of the antibacterial activity of the plant extracts was carried out in vitro by the Kirby-Bauer disc diffusion technique [1]. The strain was inoculated onto Mueller-Hinton (MH) agar plates. Sterile filter paper discs impregnated with extracts were applied over each of the culture plates. Isolates of bacteria were then incubated at $37^{\circ} \mathrm{C}$ for $24 \mathrm{~h}$. The plates were then observed for the zone of inhibition produced by the antibacterial activity of ethanolic extracts screened. A negative control disc impregnated with sterile ethanol was used in each experiment. At the end of the period, the diameters of inhibition zones formed were measured in millimeters using the vernier. For each extract, eight replicates were assayed. The plates were observed and photographs were taken. The susceptibility of the test organisms to the plant extracts was indicated by a clear zone of inhibition around the holes containing the plant extracts and the diameter of the clear zone was taken as an indicator of susceptibility.

Statistical analysis. Zone diameters were determined and averaged. Statistical analysis of the data obtained was performed by employing the mean \pm standard error of the mean (S.E.M.). All variables were randomized according to the phytochemical activity of extracts tested. All statistical calculation was performed on separate data from each strain. The data were analyzed using a one-way analysis of variance (ANOVA) using Statistica v. 8.0 software (StatSoft, Poland) [27]. The following zone diameter criteria were used to assign susceptibility or resistance of bacteria to the phytochemicals tested: Susceptible (S) $\geq 15 \mathrm{~mm}$, Intermediate $(\mathrm{I})=10-15 \mathrm{~mm}$, and Resistant $(\mathrm{R}) \leq 10 \mathrm{~mm}[16]$.

Results and discussion. The ability of the selected ethanolic plant extracts obtained from leaves of A. commutatum plants and its cultivars to inhibit E.coli growth was determined in this study. Data on antimicrobial activities of various ethanolic extracts obtained from leaves of Aglaonema commutatum plants and its cultivars ('Malay Beauty', 'Silver Queen', and 'Silver King') against Escherichia coli (Migula) Castellani and Chalmers (ATCC ${ }^{\circledR} 25922^{\mathrm{TM}}$ ) strain measured as an inhibition zone diameter are presented in Fig. 1.

Detailed data regarding the zones of inhibition by various ethanolic extracts obtained from leaves of $A$. commutatum plants and its cultivars ('Malay Beauty', 'Silver Queen', and 'Silver King') were recorded and presented in Fig. 2. 


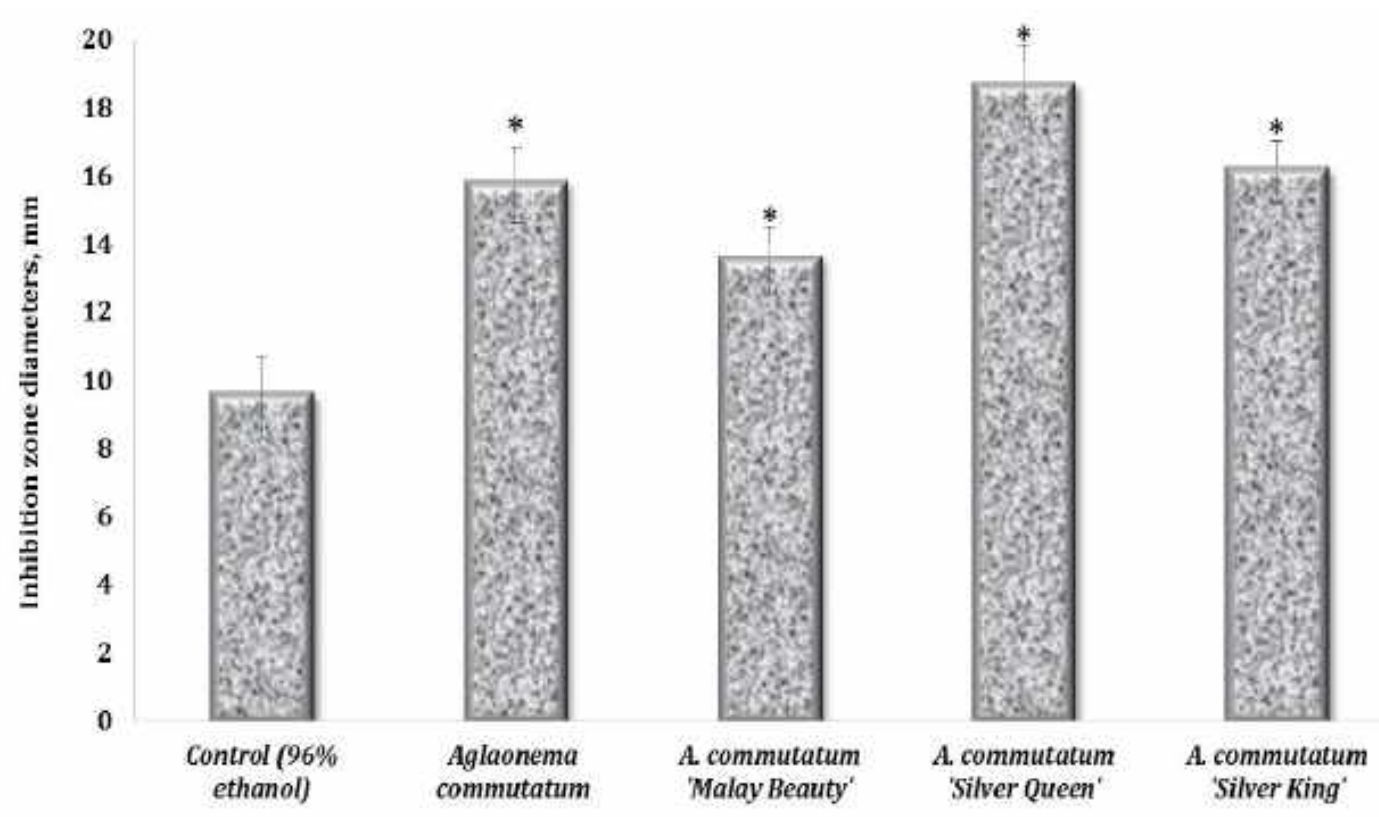

Fig. 1. The mean inhibition zone diameters around Escherichia coli (Migula) Castellani and Chalmers $\left(\mathrm{ATCC}^{\circledR} \mathbf{2 5 9 2 2}^{\mathrm{TM}}\right.$ ) growth induced by various ethanolic extracts obtained from leaves of Aglaonema commutatum plants and its cultivars ('Malay Beauty', 'Silver Queen', and 'Silver King') $(\mathbf{M} \pm \mathbf{m}, \mathbf{n}=8)$.

* - statistically significant changes $(p<0.05)$ in comparison with the control sample values $(96 \%$ ethanol).
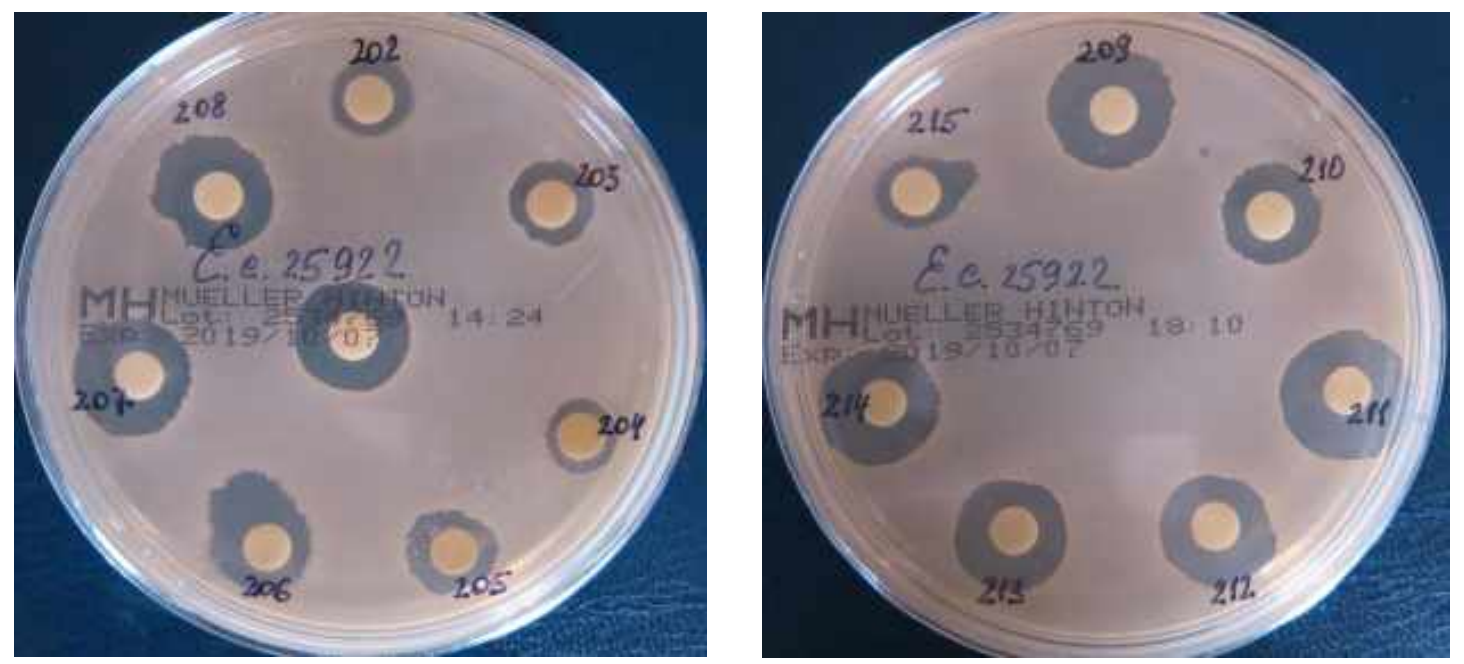

Fig. 2. Inhibition zones induced by various ethanolic extracts obtained from leaves of $A$. commutatum (207) and its cultivars ['Malay Beauty' (210), 'Silver Queen' (211), and 'Silver King' (212)] against Escherichia coli (Migula) Castellani and Chalmers $\left(\mathrm{ATCC}^{\circledR} \mathbf{2 5 9 2 2}^{\mathrm{TM}}\right.$ ) growth

E. coli is classified as a rod-shaped, Gram-negative bacterium in the family Enterobacteriaceae. The bacterium mainly inhabits the lower intestinal tract of warmblooded animals, including humans, and is often discharged into the environment through feces or wastewater effluent [11]. 
It is believed, that $E$. coli is inherently susceptible to almost all clinically relevant antimicrobial agents, but this bacterial species has a great capacity to accumulate resistance genes, mostly through horizontal gene transfer [20].

The results of our study revealed that three extracts exert high antibacterial activity against strain targeted. In particular, the leaf extracts from A. commutatum 'Silver Queen' and A. commutatum 'Silver King' exhibited higher inhibitory activity than the extracts from A. commutatum and A. commutatum 'Melay Beauty'. Maximum in vitro inhibition was scored by A. commutatum 'Silver Queen', followed by A. commutatum 'Silver King', A. commutatum, and A. commutatum "Malay Beauty', which presented inhibition zones of $(18.6 \pm 1.2) \mathrm{mm},(16.1 \pm 0.9) \mathrm{mm},(15.7 \pm 1.1) \mathrm{mm}$, and (13.5 \pm 1.0$)$ $\mathrm{mm}$, respectively. In the case of the positive controls, $96 \%$ ethanol possesses a mild anti-E. coli effect, which presented inhibition zones of $(9.5 \pm 1.2) \mathrm{mm}$. The inhibition zone diameters were increased by $96 \%(\mathrm{p}<0.05)$ for $A$. commutatum 'Silver Queen', by $69 \%$ ( $\mathrm{p}<0.05)$ for A. commutatum 'Silver King', by $65 \%(\mathrm{p}<0.05)$ for $A$. commutatum, and by $42 \%$ ( $<<0.05)$ for A. commutatum "Malay Beauty' (Fig. 1).

Very little information is available concerning the antibacterial activity of the studied plants. For instance, Roy and co-workers (2011) have screened phytochemical substances and have assayed cytotoxicity and antibacterial activities of ethanolic extracts of leaves of two medicinal plants, Aglaonema hookerianum Schott (Araceae) and Lannea coromandelica (Houtt.) Merr. (syn. Lannea grandis Engl.) (Anacardiaceae) available in Bangladesh [22].

Other plants belonging to the Araceae family also exhibited antibacterial activity. For example, Iqbal and co-workers (2018) have assessed the antibacterial activities and phytochemical content of the methanol, n-hexane, ethyl acetate, n-butanol soluble fractions, and aqueous extracts of the tubers of Arisaema jacquemontii Blume against 6 bacterial strains [7]. The data suggested that different extracts showed varying degrees of growth inhibition against the tested microbes [7]. Islam and co-workers (2013) have elucidated potential antioxidant, antidiarrheal, cytotoxic, and antibacterial activities of the ethanol extract of Alocasia indica Schott tuber in different experimental models established in vitro and in vivo [9]. Mulla and co-workers (2011) have shown that the extracts of $A$. indica have significant antidiarrheal and in vitro antiprotozoal activities that support its use in traditional herbal medicine practice. The plant extracts exhibited significant in vitro antiprotozoal activity against both protozoa compared to standard amebicidal and giardicidal drugs, metronidazole, and emetine [14].

Aglaonema hookerianum Schott (Araceae) and Lannea grandis Engl. (Anacardiaceae) extracts obtained from leaves were examined for their antibacterial activities against some Gram-positive bacteria such as Bacillus subtilis, Bacillus megaterium, and Staphylococcus aureus, also Gram-negative strains of Pseudomonas aeruginosa, Escherichia coli, Shigella dysenteriae, Salmonella typhi, Salmonella paratyphi, and Vibrio cholerae. Results indicated that both plant extracts $\left(\mu \mathrm{g} \mathrm{mL}^{-1}\right)$ displayed antibacterial activity against all tested microorganisms. The ethanolic extracts of leaves of A. hookerianum showed significant antimicrobial activity (zone of inhibition: from $15.08 \pm 0.45 \mathrm{~mm}$ to $20.37 \pm 0.45 \mathrm{~mm}$ in diameter) against all tested bacterial strains and the highest zone of inhibition was observed against $S$. paratyphi $(20.37 \pm 0.45 \mathrm{~mm})$. Similarly, the ethanolic extracts of $L$. grandis leaves also showed significant activity against all tested bacteria with a zone of inhibition ranging from $13.93 \pm 0.09 \mathrm{~mm}$ to $18.25 \pm 0.54 \mathrm{~mm}$. These results were also compared with the zones of inhibition produced by the commercially available standard antibiotic, Amoxicillin at a concentration of $10 \mu \mathrm{g}$ per disc. Observed antibacterial properties of the ethanolic extract of A. hookerianum and L. coromandelica 
showed that both plants might be useful sources for the development of new potent antibacterial agents [22].

Aglaonema treubii is a valuable source for glycosidase inhibitors that are antidiabetic, antimetastatic, antiviral, and immunomodulatory agents [3].

In our previous study [18], we focused on investigating the in vitro antibacterial activity of ethanolic extracts obtained from A. commutatum and its cultivars, cultivated under glasshouse conditions at M.M. Gryshko National Botanic Garden (NBG) against Citrobacter freundii strain locally isolated from human materials. The extracts from $A$. commutatum and A. commutatum 'Silver Queen' exhibited higher inhibitory activity than the extracts from A. commutatum 'Melay Beauty' and $A$. commutatum 'Silver King'. The highest in vitro inhibition was scored by A. commutatum, followed by A. commutatum 'Silver Queen', A. commutatum 'Malay Beauty', and A. commutatum 'Silver King'. The ethanolic extracts obtained from the leaves of Aglaonema commutatum and its cultivars have the potential for use as natural antimicrobial agents. Further in vivo and in vitro antimicrobial, phytochemical and toxicological studies are required to evaluate the chemotherapeutic effect of the plant.

Conclusions. Our research exhibited antibacterial properties of all tested extracts, but their activity was quite diverse. The leaf extracts from A. commutatum 'Silver Queen' and A. commutatum 'Silver King' exhibited higher inhibitory activity than the extracts from $A$. commutatum and A. commutatum 'Melay Beauty'. Maximum in vitro inhibition was scored by A. commutatum 'Silver Queen', followed by A. commutatum 'Silver King', A. commutatum, and A. commutatum "Malay Beauty'. Thus, as a result of the research, the use of these plants in traditional medicine and veterinary medicine was experimentally confirmed as a potential source of raw materials for the development of medicines in the future, as well as for the development of innovative feed for farm animals. In considering the outcome of this study, further in vivo and in vitro antimicrobial, phytochemical and toxicological studies are required to evaluate the chemotherapeutic effect of the plant.

\section{References}

1. Bauer, A. W., Kirby, W. M., Sherris, J. C., Turck, M. (1966). Antibiotic susceptibility testing by a standardized single disk method. Am. J. Clin. Pathol., 45(4), 493-496.

2. Chee, C. F., Leea, H. B., Ong, H. C., Ho, A. S. H. (2005). Photocytotoxic Pheophorbide-Related compounds from Aglaonema simplex. Chem. Biodivers., 2(12), $1648-1655$.

3. Chen, J., Henny, R. J., Liao, F. (2007). Aroids are important medicinal plants. Acta Hortic., 756, 347-354.

4. Chen, J., Henny, R. J., McConnell, D. B. (2002). Development of new foliage plant cultivars. p. 466-472. In: J. Janick and A. Whipkey (eds.), Trends in new crops and new uses, Timber Press, Inc., Portland, Ore.

5. Chen, J., McConnell, D. B., Henny, R. J., Everitt, K. C. (2003). Cultural guidelines for commercial production of interiorscape Aglaonema. TFAS Extension EnH95, Univ. Florida, (pp. 1-5).

6. Govaerts, R., Frodin, D. G. (2002). World checklist and bibliography of Araceae (and Acoraceae), Royal Bot. Gard., Kew, UK, p. 1-560.

7. Iqbal, M., Bakht, J., Shafi, M. (2018). Phytochemical screening and antibacterial activity of different solvent extracted samples of Arisaema jacquemontii. Pak. J. Pharm. Sci., 31(1), 75-81. 
8. Islam, A., Kamal, T., Hosen, M., Sharmin, N., Hossain, S., Islam, N. (2019). Lethal efficacy of indoor ornamental plant Aglaonema marantifolium (Schott.) against three economically important stored product pests Callosobruchus chinensis (L.), Sitophilus oryzae (L.) and Tribolium castaneum (HBST.). Journal of Pharmacognosy and Phytochemistry, 8(1), 2198-2201.

9. Islam, A., Mahmud, I., Saha, S., Sarker, A. B., Mondal, H., Monjur-AlHossain, A. S., Anisuzzman, M. (2013). Preliminary pharmacological evaluation of Alocasia indica Schott tuber. J. Integr. Med., 11(5), 343-351.

10. Ismail, Z., Ahmad, A. (2017). Phytochemical screening of in vitro Aglaonema simplex plantlet extracts as inducers of SR-B1 ligand expression. Journal of Sustainability Science and Management, 12(2), 34-44.

11. Jang, J., Hur, H. G., Sadowsky, M. J., Byappanahalli, M. N., Yan, T., Ishii, S. (2017). Environmental Escherichia coli : ecology and public health implications - a review. J. Appl. Microbiol., 123(3), 570-581.

12. Kiatsongchai, R. (2015). Biological properties and toxicity of wan khan mak (Aglaonema simplex B1.) Fruit extract. A Thesis Submitted in Partial Fulfillment of the Requirements for the Degree of Doctor of Philosophy in Environmental Biology Suranaree University of Technology, (pp. 176).

13. Mayo, D. J., Bogner, J., Boyce, P. C. (1997). The genera of Araceae. Royal Botanic Gardens, Kew.

14. Mulla, W. A., Chopade, A. R., Bhise, S. B., Burade, K. B., Khanwelkar, C. C. (2011). Evaluation of antidiarrheal and in vitro antiprotozoal activities of extracts of leaves of Alocasia indica. Pharm. Biol., 49(4), 354-361

15. Nojima, H., Kimura, I., Chen, F. J., Sugihara, Y., Haruno, M., Kato, A., Asano, N. (1998). Antihyperglycemic effects of N-containing sugars from Xanthocercis zambesiaca, Morus bombycis, Aglaonema treubii, and Castanospermum australe in streptozotocin-diabetic mice. J. Nat. Prod., 61(3), 397-400.

16. Okoth, D. A., Chenia, H. Y., Koorbanally, N. A. (2013). Antibacterial and antioxidant activities of flavonoids from Lannea alata (Engl.) Engl. (Anacardiaceae). Phytochem. Lett., 6, 476-481.

17. Opryshko, M., Gyrenko, O., Tkachenko, H., Buyun, L., Osadowski, Z. (2019). Dose-depended protective effect of the Aglaonema simplex (Blume) Blume leaf extract on the resistance of human erythrocytes. Abstract Proceedings of II International scientific conference „The present of biological science”, Sumy State Pedagogical University named after A.S. Makarenko, Sumy, (pp. 130-137).

18. Opryshko, M., Tkachenko, H., Buyun, L., Kurhaluk, N., Góralczyk, A., Tomin, W., Osadowski, Z. (2019). Evaluation of the antibacterial activity of ethanolic extracts obtained from Aglaonema commutatum Schott and its cultivars against Citrobacter freundii. Agrobiodiversity for Improving Nutrition, Health, and Life Quality, (3), 154-164.

19. Perry, L. M. (1980). Medicinal Plants of East and Southeast Asia. Attributed properties and uses. M.I.T. Press, Cambridge, MA.

20. Poirel, L., Madec, J. Y., Lupo, A., Schink, A. K., Kieffer, N., Nordmann, P., Schwarz, S. (2018). Antimicrobial Resistance in Escherichia coli. Microbiol. Spectr., 6(4).

21. Rajput, M. T., Choufhary, M. I., Naimul-Hasan Naqvi, S., Abbas, A. (2010). Importance and implementation of essential oil of Pakistanian Acorus calamus Linn. as a biopesticide. Pak. J. Bot., 42(3), 2043-2050. 
22. Roy, A., Biswas, S. K., Chowdhury, A., Shill, M. C., Raihan, S. Z., Muhit, M. A. (2011). Phytochemical screening, cytotoxicity and antibacterial activities of two Bangladeshi medicinal plants. Pak. J. Biol. Sci., 14(19), 905-908.

23. Roy, S., Dutta, CH., Paul, S. B. (2013). Antibacterial activity of Araceae: An overview. International Journal of Research in Ayurveda and Pharmacy, 4(1), 1517.

24. Tabassum, S., Ahmed, M., Mirza, B., Naeem, M., Zia, M., Shanwari, Z. K., Khan, G. M. (2017). Appraisal of phytochemical and in vitro biological attributes of an unexplored folklore: Rhus Punjabensis Stewart. BMC Complement. Altern. Med., 17(1), 146.

25. Tabassum, S., Zia, M., Carcahe de Blanco, E. J., Batool, R., Aslam, R., Hussain, S., Wali, Q., Gulzar, M. M. (2019). Phytochemical, in-vitro biological and chemo-preventive profiling of Arisaema jacquemontii Blume tuber extracts. BMC Complement. Altern. Med., 19(1), 256.

26. Yadav, R., Agarwala, M. (2011). Phytochemical analysis of some medicinal plants. J. Phytol., 3(12), 10-14.

27. Zar, J. H. (1999). Biostatistical Analysis. $4^{\text {th }}$ ed., Prentice-Hall Inc., Englewood Cliffs, New Jersey.

ВИЗНАЧЕННЯ АНТИБАКТЕРІАЛЬНОЇ ЕФЕКТИВНОСТІ ЕТАНОЛЬНИХ ЕКСТРАКТIВ IЗ ЛИСТКIB AGLAONEMA COMMUTATUM SCHOTT TA COPTIB ЦЬОГО ВИДУ ПО ВІДНОШЕННЮ ДО ШТАМУ ESCHERICHIA COLI

Опришко М., Гиренко О., Буюн Л., Національний ботанічний сад імені М. М. Гришка, Національна академія наук України.

Ткаченко Г., Кургалюк Н., Інститут біології та наук про Землю, Поморська Академія у Слупську, Польща.

Томін В., Поморська Академія у Слупську, Польща.

Метою дослідження стала оцінка антибактеріальної активності етанольних екстрактів, отриманих з листя Aglaonema commutatum Schott i його copmiв («Malay Beauty», "Silver Queen», u «Silver King») nроти штамів Escherichia coli (Migula) Castellani i Chalmers (ATCC ${ }^{\circledR} 25922$ тм). Зразки листя рослин Aglaonema coтmиtatum $i$ їх сортів культивованих в тепличних умовах, були відібрані в Національному ботанічному саду ім. М. М. Гришко Національної академії наук України (м. Киї, Україна). Листя були доставлені в лабораторію для антимікробних досліджень. Свіжозібране листя промивали, зважували і гомогенізували в 96\% - ному етанолі (в пропориії 1: 19) при кімнатній температурі. Потім екстракти фільтрували і досліджували на предмет їх антимікробної активності. У досліді використовували итам Escherichia coli (Migula) Castellani ma Chalmers (ATCC ${ }^{\circledR}$ 25922 TM).

Тестування антимікробної активності рослинних екстрактів здійснювали за умов in vitro з використанням диско-дифузійного методу Кірбі-Бауера. Екстракти листків A. commиtatum 'Silver Queеn' i A. commutatum 'Silver King' виявили вищу інгібуючу активність, ніж екстракти, отримані з листків А. соттитатит ma A. coтmиtatum 'Melay Beauty'. Максимальне інгібування росту мікроорганізма in vitro було зумовлено екстрактами листків A. commutatum 'Silver Queеn'; зниження інгібування виявили екстракти листків у наступній послідовності: A. commutatum 'Silver King', A. commutatum i A. commutatum "Malay Beauty'.

Зокрема, екстракти листя від A. coтmutatum «Silver Queen» $i$ A. commutatum «Silver King», характеризуються вищою інгібуючою активністю, ніж витяжки з А. соттитаtит и A. соттитаtит «Malay Beauty». Максимальне ин- 
гібування in vitro було відмічене A. commutatum «Silver Queеn», за яким слідували A. commutatum «Silver King», A. commutatum u A. commutatum "Malay Beauty», 8 якому представлені зони інгібування $(18,6 \pm 1,2)$ мм, $(16,1 \pm 0,9)$ мм, $(15,7 \pm 1,1)$ мм и $(13,5 \pm 1,0)$ мм відповідно. У разі позитивного контролю 96\% етанол володіє м'яким анти-E. coli ефектом, який представлений зонами інгібування $(9,5 \pm 1,2)$ мм. Діаметри зон інгібування були збільшені на $96 \%(p<0,05)$ для А. соттитаtuт "Silver Queen», на $69 \%(p<0,05)$ для A. commutatum «Silver King», на $65 \%$ $(p<0,05)$ для A. commutatum і на $42 \%(p<0,05)$ для A. commutatum «Malay Beauty».

Таким чином, у результаті виконаного дослідження було експериментально підтверджено застосування ичих рослин у традиційній медицині і ветеринарії, як потенційного джерела сировини для розробки лікарських засобів у майбутньому, а також для розробки іновачійних кормів для сільськогосподарських тварин.

Ключові слова: Aglaoneта соттитатит, антимікробна активність, итам Escherichia coli (Migula) Castellani and Chalmers (ATCC ${ }^{\circledR} 25922^{\mathrm{TM}}$ ), дискодифузійний метод Кірбі-Бауера

ОПРЕДЕЛЕНИЕ АНТИБАКТЕРИАЛЬНОЙ Т ЭФФЕКТИВНОСТИ ЭТАНОЛЬНЫХ ЭКСТРАКТОВ ЛИСТЬЕВ AGLAONEMA COMMUTATUM

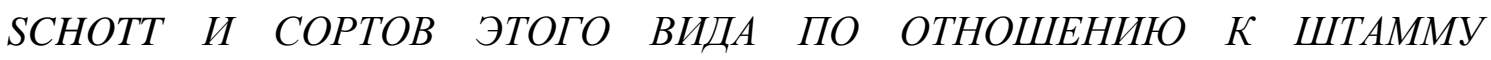
ESCHERICHIA COLI

Опришко М., Гиренко А., Буюн Л., Начиональный ботанический сад имени Н. Н. Гришко, Национальная академия наук Украины,

Ткаченко Г., Кургалюк Н., Институт биологии и наук о Земле, Поморская Академия в Слупске, Польша

Томин В., Поморская Академия в Слупске, Польша

Целью исследования стала оценка антибактериальной активности этанольных экстрактов, полученных из листьев Aglaonema commutatum Schott и его сортов ("Malay Beauty», «Silver Queen», u «Silver King») против итаммов Escherichia coli (Migula) Castellani u Chalmers (ATCC ® 25922 тм). Образиьл листьев растений Aglaoneта соттитаtит и их сортов культивируемых в тепличных условиях, были отобраны в Национальном ботаническом саду им. М. М. Гришко Национальной академии наук Украинь (г. Киев, Украина). Листья были доставлень в лабораторию для антимикробных исследований. Свежесобранные листья промыввали, взвешивали и гомогенізували в 96 \% - ном этаноле (в пропорции 1: 19) при комнатной температуре. Затем экстракты фильтровали и исследовали на предмет их антимикробной активности. В опьте использовали итамм Escherichia coli (Migula) Castellani u Chalmers (ATCC ${ }^{\circledR} 25922$ тм). Тестирование антимикробной активности растительных экстрактов осуществляли в условиях in vitro с использованием диско-диффузионного метода Кирби-Бауэра. Экстрактыл листьев сортов A. commutatum «Silver Queen» и A. commutatum "Silver King» оказали более высокую ингибирующую активность, чем экстракты, полученные из листьев A. commutatum и A. commutatum 'Melay Beauty'. Максимальное ингибирование роста микроорганизма in vitro было вызвано экстрактами листьев A. commutatum «Silver Quеen»; далее, снижение ингибирование было отмечено в следуюшей последовательности: A. commutatum «Silver King», A. commutatum u A. commutatum «Malay Beauty».

В частности, экстракты листьев от A. commutatum «Silver Queen» $u$ A. commutatum «Silver King», выставленные выме ингибирующей активностью, чем выдержки из A. соттитаtит и A. coтmиtatum «Malay Beauty». Максимальное ингибирование in vitro было отмечено A. commutatum «Silver Queen», за которым 
следовали A. commutatum «Silver King», A. commutatum и A. коммутатум «Malay Beauty», в котором представлены зоны ингибирования $(18,6 \pm 1,2)$ мм, $(16,1 \pm 0,9)$ мм, $(15,7 \pm 1,1)$ мм и $(13,5 \pm 1,0)$ мм соответственно. В случае положительного контроля 96\% этанол обладает мягким анти - E. coli эффектом, который представлен зонами ингибирования $(9,5 \pm 1,2)$ мм. диаметры зон ингибирования были увеличены на 96\% $(p<0,05)$ для A. commutatum «Silver Queen», на 69\% $(p<0,05)$ для A. commutatum «Silver King», на 65\% $(p<0,05)$ для A. commutatum и на $42 \%$ $(p<0,05)$ для A. commutatum «Malay Beauty».

Таким образом, в результате выполненного исследования было экспериментально подтверждено применение этих растений в традиционной медицине и ветеринарии, как потенциального источника сырья для разработки лекарственных средств в будущем, а также для разработки инновачионных кормов для сельскохозяйственных животных.

Ключевые слова: Aglaonema coтmutatum, антимикробная активность, uтамм Escherichia coli (Migula) Castellani and Chalmers $\left(\right.$ ATCC $\left.^{\circledR} 25922^{\mathrm{TM}}\right)$, дискодиффузионный метод Кирби-Бауэра

DOI 10.32900/2312-8402-2020-123-30-38

УДК 615.012.1: 582.949.2: 581.3

\title{
IN VITRO SCREENING FOR ANTIMICROBIAL POTENTIAL OF ETHANOLIC LEAF EXTRACTS OF SOME BEGONIA SPECIES AGAINST METHICILLIN-RESISTANT STAPHYLOCOCCUS AUREUS (MRSA) STRAIN
}

\author{
Tkachenko H., Doctor of Biological Sciences \\ Kurhaluk N., Doctor of Biological Sciences \\ Institute of Biology and Earth Sciences, Pomeranian University in Słupsk, Poland \\ Buyun L., Doctor of Biological Sciences \\ M. M. Gryshko National Botanic Garden, National Academy of Science of Ukraine \\ Tomin V., Doctor of Physical Sciences \\ Pomeranian University in Słupsk, Poland
}

The antimicrobial activities of ethanolic extracts obtained from the leaves of Begonia solimutata L.B. Sm. \& Wassh., Begonia goegoensis N.E.Br., Begonia foliosa Kunth, Begonia $\times$ erythrophylla Hérincq, Begonia thiemei C.DC., Begonia peltata Otto \& Dietr., Begonia heracleifolia Cham. \& Schltdl., Begonia dregei Otto \& Dietr., and Begonia mexicana G. Karst. ex Fotsch were assessed against methicillin-resistant Staphylococcus aureus (MRSA) strain. The leaves were brought into the laboratory for antimicrobial studies. Freshly crushed leaves were washed, weighed, and homogenized in 96\% ethanol (in proportion 1:19) at room temperature. The extracts were then filtered and investigated for their antimicrobial activity. The testing of the antibacterial activity of the plant extracts was carried out in vitro by the Kirby-Bauer disc diffusion susceptibility test protocol. The most effective plants among species screened against $S$. aureus NCTC 12493 growth were B. peltata, B. thiemei, B. foliosa, Begonia $\times$ erythrophylla, and B. solimutata being highly active with the ethanolic extracts (diameters of inhibition zone ranged from 12.5 to $21 \mathrm{~mm}$ ). The ethanolic extracts from nine Begonia plant species were evaluated for their antimicrobial activity against methicillinresistant S. aureus (MRSA) strain. Extracts from all test Begonia plants caused a re- 